\title{
Woody Species Regeneration in Atlantic Forest Restoration Sites Depends on Surrounding Landscape
}

\author{
Lya Carolina da Silva Mariano Pereira, Carolina de Cássia Cainelli de Oliveira \& \\ José Marcelo Domingues Torezan*
}

Laboratório de Biodiversidade e Restauração de Ecossistemas, Programa de Pós-graduação em Ciências Biológicas, Universidade Estadual de Londrina - UEL, Londrina, PR, Brazil

\begin{abstract}
Both passive and active restoration are limited by diaspore arrival from neighboring sources. Surrounding landscape is thus important for restoration success in fragmented landscapes, where reforestation, for long periods, may be limited to the planted species pool. We sampled woody species regeneration in 17 reforestation sites in Southern Brazil to investigate the effects of distance to seed sources and amount of remaining nearby Atlantic Forest habitat. The abundance and species richness of regenerating plants were explained by multiple regressions performed using plantation age and species richness, distance to the nearest patch, and surrounding habitat. Distance to the nearest forest remnant, through both the matrix in a straight line and riparian vegetation, was the best predictor of species richness and abundance of regenerating plants. Riparian corridors doubled the distance at which forest remnants influenced restoration sites. However, the area of forest remnants in the site neighborhood did not influence regeneration diversity, suggesting that the quality of both the seed source (including the status of seed dispersing fauna) and reforestation environment for the establishment of forest species should be investigated.
\end{abstract}

Key words: Forest Fragmentation, Seed Dispersal, Ecological Restoration, Secondary Succession.

\section{Introduction}

The Atlantic Forest has suffered extensive deforestation over the last five centuries due to agriculture, cattle raising, and urban growth. Today, in most regions the landscapes are fragmented, with forest cover limited to small patches and a huge amount of degraded area needing to be revegetated to comply with conservation goals and enhance landscape connectivity (Ribeiro et al. 2009).

The present landscape's spatial configuration may influence local ecological processes, mainly by decreasing biological flows such as seed dispersal (Hamilton 1999; Tabarelli et al. 1999; Tabarelli \& Peres 2002). Thus, secondary succession, whether preceded by active restoration or not, may be delayed or even precluded if the local biota is constrained to a few already present or actively reintroduced species (Hobbs \& Norton 1996; Holl et al. 2000). Active ecological restoration frequently relies on overcoming site limitations, such as an unfavorable microclimate and soil degradation, by means of planting or promoting the establishment of a limited pool of rustic species that is expected to change the site conditions (Parrotta et al. 1997; Sansevero et al. 2011).

\footnotetext{
*Send correspondence to: José Marcelo Torezan

Laboratório de Biodiversidade e Restauração de Ecossistemas, Programa de Pós-graduação em Ciências Biológicas,

Universidade Estadual de Londrina - UEL, CEP 86057-970,

Londrina, PR, Brazil

E-mail: torezan@uel.br
}

However, it is difficult, if not impossible, to manipulate a large set of species and functional groups to actively assemble a complex ecosystem without counting on spontaneous species arrival from neighboring sources (Parrotta et al. 1997). Although it is possible to introduce a relatively large number of species during the implementation of reforestation, many late species would not adapt to local abiotic conditions. Therefore, most unplanted species will depend on existing neighboring sources of propagules to reach restoration sites. Besides seed source distance, the size and quality of these sources can influence the arriving species richness as long as larger and better-conserved habitat tracts will hold more species (Fahrig 2003; Aparicio et al. 2008).

Differences in dispersal syndrome (White et al. 2004), seed mass (Laurance 1994; Moles \& Westoby 2004), and microhabitat preferences (Holl 1999) among plants species can result in different abilities to cross the landscape and to arrive at successional sites. Most of the uncertainty regarding plant dispersal ability can be related to their dispersal agent's ability to cross the matrix among habitat patches, an issue that is of great interest to researchers (Taylor et al. 1993; Metzger \& Décamps 1997; Wunderle Jr. 1997; Pivello et al. 2006). It is worth stating that both plants and their dispersal agents will show a great range in their dispersal abilities in fragmented landscapes (White et al. 2004). While wind-dispersed species benefit from a non-forest matrix, animal-dispersed species 
rely on the vagility of dispersing animal species. However, if there is a threshold in landscape fragmentation after which dispersal will fall to near zero (Metzger \& Décamps 1997) regardless of species dispersal syndrome, knowing such a limit will be crucial for the planning, establishment, and management of restoration sites.

A few studies have been conducted relating fragmented landscapes and restoration sites, especially regarding passive succession in reforestation and the distance from seed sources. Some of these studies have shown that the recruitment of late-successional, forest specialist species is slower in isolated sites compared with sites adjacent to sources (Zanne \& Chapman 2001; White et al. 2004). To mitigate the negative effects of distance from seed sources in fragmented landscapes, it is important to increase the connectivity of the matrix, and one of the best methods is to promote habitat restoration in some agricultural sites (García-Feced et al. 2011) and riparian lands (DeClerck et al. 2010). Furthermore, restoration sites and other early successional habitats represent a good opportunity to test hypotheses about biotic dispersal in fragmented landscapes, due to their simple structure and known history, unlike most forest remnants.

In this study, we investigate how and to what extent woody plant diversity in the understory of reforestation sites is related to the distance from seed sources and to the amount of neighboring Atlantic Forest habitat. We hypothesized that the abundance and richness of late successional, forest dependent species and animal-dispersed species will be low at further isolated sites.

\section{Methods}

\section{Study sites}

To analyze the influence of nearby landscape structures on native plant species regeneration, 17 reforestation sites of similar ages (75 to 101 months) at different distances from Atlantic Forest remnants were studied. The forest cover in a 1000 -m radius from each site ranged from 2.3 to 35.3 ha (see Table 1 in the supplementary material ${ }^{\star *}$ ). Study sites were

Table 1. Results of multiple regression analysis for non-planted, native woody species diversity in restoration sites $(\mathrm{N}=17)$ in northern Paraná state, Brazil. A - total abundance, $S$ - total species richness, $A_{L}$ - abundance of late successional species, $S_{L}$ - richness of late successional species, $A_{A}$ - abundance of animal-dispersed species, $S_{A}$ - richness of animal-dispersed species, $D$ - distance to nearest forest remnant, $D_{V}$ - distance to nearest forest remnant through riparian vegetation, $Y$ - plantation age, $\mathrm{P}$ - planted species richness, $\mathrm{V}_{500}$ - surrounding forest area in $500 \mathrm{~m}$ radius, $\mathrm{V}_{1000}$ - surrounding forest area in $1000 \mathrm{~m}$ radius and $\mathrm{A}_{\mathrm{NF}}$ - abundance of non-forest species. ${ }^{\star}$ Best models. Best independent variable: significance in simple linear regression with highest $\mathrm{r}^{2}$.

\begin{tabular}{|c|c|c|c|c|c|c|c|}
\hline $\begin{array}{l}\text { Dependent } \\
\text { Variable }\end{array}$ & Model & $\mathbf{r}^{2}$ & $\begin{array}{c}\mathbf{r}^{2} \\
\text { adjusted }\end{array}$ & model $p$ & $\begin{array}{c}\text { best } \\
\text { independent } \\
\text { variable }\end{array}$ & beta & $p$ \\
\hline \multirow[t]{4}{*}{ A } & D Y P V ${ }_{500} A_{\mathrm{NF}}$ & 0.495 & 0.265 & 0.13 & - & - & - \\
\hline & D Y P V $1000 A_{\mathrm{NF}}$ & 0.642 & 0.454 & 0.03 & $\mathrm{D}$ & -0.75 & 0.01 \\
\hline & $\mathrm{D}_{\mathrm{V}} \mathrm{Y} \mathrm{P} \mathrm{V}_{500} \mathrm{~A}_{\mathrm{NF}}$ & 0.586 & 0.398 & 0.05 & $\mathrm{D}_{\mathrm{v}}$ & -0.58 & 0.03 \\
\hline & $\mathrm{D}_{\mathrm{V}} \mathrm{Y} \mathrm{P} \mathrm{V}_{1000} \mathrm{~A}_{\mathrm{NF}}^{*}$ & 0.731 & 0.609 & 0.006 & $\mathrm{D}_{\mathrm{V}}$ & -0.84 & 0.001 \\
\hline \multirow[t]{4}{*}{$S$} & D Y P V $\mathrm{V}_{500} \mathrm{~A}_{\mathrm{NF}}$ & 0.555 & 0.353 & 0.07 & $\mathrm{D}$ & -0.57 & 0.04 \\
\hline & D Y P V $1000 A_{\mathrm{NF}}$ & 0.632 & 0.465 & 0.03 & $\mathrm{D}$ & -0.75 & 0.01 \\
\hline & $\mathrm{D}_{\mathrm{V}} \mathrm{Y} \mathrm{P} \mathrm{V}_{500} \mathrm{~A}_{\mathrm{NF}}$ & 0.627 & 0.457 & 0.03 & $\mathrm{D}_{\mathrm{v}}$ & -0.64 & 0.01 \\
\hline & $\mathrm{D}_{\mathrm{V}} \mathrm{Y} \mathrm{P} \mathrm{V}_{1000} \mathrm{~A}_{\mathrm{NF}}^{*}$ & 0.705 & 0.571 & 0.01 & $\mathrm{D}_{\mathrm{V}}$ & -0.80 & 0.002 \\
\hline \multirow[t]{4}{*}{$\mathrm{A}_{\mathrm{L}}$} & D Y P V $\mathrm{V}_{500} \mathrm{~A}_{\mathrm{NF}}$ & 0.488 & 0.256 & 0.14 & - & - & - \\
\hline & D Y P V $1000 A_{\mathrm{NF}}$ & 0.602 & 0.421 & 0.04 & $\mathrm{D}$ & -0.74 & 0.01 \\
\hline & $\mathrm{D}_{\mathrm{V}} \mathrm{Y} \mathrm{P} \mathrm{V}_{500} \mathrm{~A}_{\mathrm{NF}}$ & 0.569 & 0.374 & 0.06 & $\mathrm{D}_{\mathrm{V}}$ & -0.57 & 0.03 \\
\hline & $\mathrm{D}_{\mathrm{V}} \mathrm{Y} \mathrm{P} \mathrm{V}_{1000} \mathrm{~A}_{\mathrm{NF}}^{*}$ & 0.694 & 0.554 & 0.01 & $\mathrm{D}_{\mathrm{V}}$ & -0.81 & 0.002 \\
\hline \multirow[t]{4}{*}{$\mathrm{S}_{\mathrm{L}}$} & D Y P V ${ }_{500} A_{\mathrm{NF}}$ & 0.489 & 0.258 & 0.14 & - & - & - \\
\hline & D Y P V ${ }_{1000} A_{\mathrm{NF}}^{*}$ & 0.503 & 0.277 & 0.12 & $\mathrm{D}$ & -0.68 & 0.03 \\
\hline & $\mathrm{D}_{\mathrm{V}} \mathrm{Y} \mathrm{P} \mathrm{V}_{500} \mathrm{~A}_{\mathrm{NF}}$ & 0.486 & 0.252 & 0.14 & - & - & - \\
\hline & $\mathrm{D}_{\mathrm{V}} \mathrm{Y} \mathrm{P} \mathrm{V} \mathrm{V}_{1000} \mathrm{~A}_{\mathrm{NF}}$ & 0.489 & 0.256 & 0.14 & $\mathrm{D}_{\mathrm{v}}$ & -0.64 & 0.04 \\
\hline \multirow[t]{4}{*}{$\mathrm{A}_{\mathrm{A}}$} & D Y P V $V_{500} A_{\mathrm{NF}}$ & 0.494 & 0.263 & 0.13 & - & - & - \\
\hline & D Y P V ${ }_{1000} A_{\mathrm{NF}}$ & 0.578 & 0.387 & 0.05 & $\mathrm{D}$ & -0.64 & 0.03 \\
\hline & $\mathrm{D}_{\mathrm{V}} \mathrm{Y} \mathrm{P} \mathrm{V}_{500} \mathrm{~A}_{\mathrm{NF}}$ & 0.551 & 0.347 & 0.07 & - & - & - \\
\hline & $\mathrm{D}_{\mathrm{V}}$ Y P V $\mathrm{V}_{1000} \mathrm{~A}_{\mathrm{NF}}^{*}$ & 0.646 & 0.485 & 0.02 & $\mathrm{D}_{\mathrm{v}}$ & -0.70 & 0.01 \\
\hline \multirow[t]{4}{*}{$\mathrm{S}_{\mathrm{A}}$} & D Y P V ${ }_{500} A_{\mathrm{NF}}$ & 0.596 & 0.412 & 0.04 & $\mathrm{D}$ & -0.61 & 0.02 \\
\hline & D Y P V ${ }_{1000} A_{\mathrm{NF}}$ & 0.652 & 0.494 & 0.02 & $\mathrm{D}$ & -0.76 & 0.008 \\
\hline & $\mathrm{D}_{\mathrm{V}} \mathrm{Y} \mathrm{P} \mathrm{V}_{500} \mathrm{~A}_{\mathrm{NF}}$ & 0.639 & 0.476 & 0.02 & $\mathrm{D}_{\mathrm{V}}$ & -0.64 & 0.01 \\
\hline & $\mathrm{D}_{\mathrm{V}} \mathrm{Y} \mathrm{P} \mathrm{V} \mathrm{V}_{1000} \mathrm{~A}_{\mathrm{NF}}^{*}$ & 0.690 & 0.550 & 0.01 & $\mathrm{D}_{\mathrm{v}}$ & -0.77 & 0.004 \\
\hline
\end{tabular}

${ }^{* *}$ see supplementary material available at abeco.org.br. 
located in the margins of the Capivara Reservoir (north of Parana state, Brazil; between $22^{\circ} 45^{\prime} 22^{\prime \prime} \mathrm{S}, 51^{\circ} 98^{\prime} 38^{\prime \prime} \mathrm{W}$ and $23^{\circ} 06^{\prime} 16^{\prime \prime} \mathrm{S}, 50^{\circ} 51^{\prime} 27^{\prime \prime} \mathrm{W}$ ). The original vegetation cover was a seasonal form of the Atlantic Forest, which presently covers less than $2 \%$ of the region. The forest remnants are late successional and suffered limited timber extraction in the early 1980s, ranging from 4 to 180 ha in size.

The climate is classified as Köeppen's Cfa humid subtropical, with hot, humid summers. Frosts are infrequent, and rain is concentrated in the summer months (December-January), with no definite dry season. The average temperature in the warmest month (January) is approximately $23.8^{\circ} \mathrm{C}$ and that in the coldest month (July) is $16.8^{\circ} \mathrm{C}$. Precipitation averages $201.4 \mathrm{~mm}$ in January (summer) and $56.5 \mathrm{~mm}$ in July (winter). The soil at all sites is a highly fertile eutrophic red latosol, originated from basaltic rock and used in soybean and maize rotation until the reforestation activities began. All the reforestation sites are also surrounded by maize and soybean plantations.

All reforestation sites were on strips of land between $334 \mathrm{~m}$ (maximum reservoir water level) and $338 \mathrm{~m}$ above sea level, by means of planting native, pioneer, and early secondary species, with $2 \times 3 \mathrm{~m}$ spacing between seedlings. The planted species richness varied between 25 and 50 species. Weed control was done by mechanical and manual mowing until the end of the $2^{\text {nd }}$ year after planting. During weed control, all regenerating individuals (native and non-native woody species) were also removed.

\section{Data collection}

In each site, ten $10-\times 10$-m plots were established along reforestation strips, with a minimum of a $20 \mathrm{~m}$ distance between them (see supplementary material). In each plot, all woody plants with a height equal or greater than 0.10 $\mathrm{m}$ were identified and counted. The regenerating plant species were also classified as early or late successional species (see supplementary material), by dispersal syndrome (self-, wind- or animal-dispersed), as native or exotic, and as forest or non-forest species. Regenerating individuals from exotic species, reforestation-planted species, and non-forest species were excluded from analysis because the arrival of the diaspores of these species does not depend on the remnant forest-originated seed rain. Abundance (A) and richness $(S)$ were analyzed separately, and both were determined for three groups: (1) native species (A/S), (2) late successional species $\left(\mathrm{A}_{\mathrm{L}} / \mathrm{S}_{\mathrm{L}}\right)$, and (3) animal-dispersed species $\left(\mathrm{A}_{\mathrm{A}} / \mathrm{S}_{\mathrm{A}}\right)$.

To measure the amount of surrounding habitat and distance to the nearest forest remnant, a thematic map based on LANDSAT 7 imagery was generated (scene 222/76 from September 2003). Forest habitat area was measured in 500- and 1000-m radius neighborhoods for each reforestation site $\left(\mathrm{V}_{500}\right.$ and $\mathrm{V}_{1000}$, respectively). The distance to the nearest forest remnant of at least 4 ha was measured from the plots to the remnants, both directly in a straight line (D) and through a reforestation strip, thereby minimizing travel in the matrix $\left(D_{V}\right)$ (see supplementary material). We also used the abundance of non-forest species $\left(\mathrm{A}_{\mathrm{NF}}\right)$ to track possible differences in the negative effects of these species on native woody species among sites. The effects of both planted species richness $(\mathrm{P})$ and stand age $(\mathrm{Y})$ were also investigated.

\section{Data analysis}

All dependent variables were log-transformed for analysis. Multiple linear regressions were used to find better predictors for the abundance and richness of unplanted woody species native to Atlantic Forest. The model was deemed significant when $\mathrm{p} \leq 0.05$. To identify the best model, the higher adjusted $r^{2}$ value was used.

\section{Results}

From the plots, 13,766 plants taller than $0.10 \mathrm{~m}$ distributed among 31 families and 80 species were sampled, mostly of native (84.6\%), animal-dispersed (56.4\%), and early successional species $(78.2 \%)$. With the elimination of all planted, exotic, and non-forest species, only 1029 plants remained, distributed into 14 families and 20 species, mostly of animal-dispersed (90\%) and late successional species $(70 \%)$ (see the supplementary material for species list).

The multiple regression analysis identified some models that explained a significant portion of the variability in the diversity of woody plants in the studied sites. However, most of the variables included in the models were not significant alone, and no significant model accounted for late successional species (Table 1).

Both $\mathrm{D}$ and $\mathrm{D}_{\mathrm{V}}$ were significant in models explaining abundance $\left(A, A_{L}\right.$, and $\left.A_{A}\right)$ and species richness variables $\left(\mathrm{S}\right.$ and $\mathrm{S}_{\mathrm{A}}$ ) (Table 1). An increase in distance reduced both the abundance (Figure 1) and species richness (Figure 2) of regenerating plants; at distances of approximately $4000 \mathrm{~m}$ (through matrix) or $8000 \mathrm{~m}$ (through riparian corridors), the number of non-planted regenerating plants tended toward zero.

Neither measure of neighborhood forest habitat $\left(\mathrm{V}_{500}\right.$ or $\mathrm{V}_{1000}$ ) served as a predictor of species richness in simple regressions (which are shown in supplementary material), but $\mathrm{V}_{1000}$ was significant in one of the models (Table 1).

\section{Discussion}

Given their restricted ranges of values, the abundance of non-forest species, stand age, and richness of planted species did not significantly influence woody species richness and abundance, and thus, can be considered to be controlled in this study. 

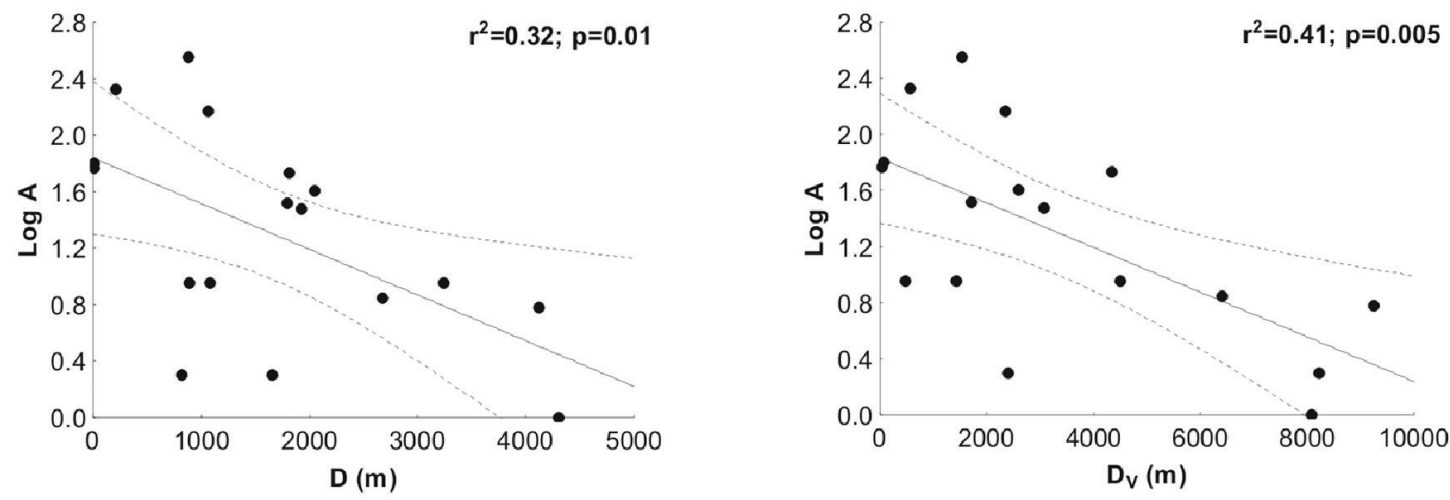

(c)
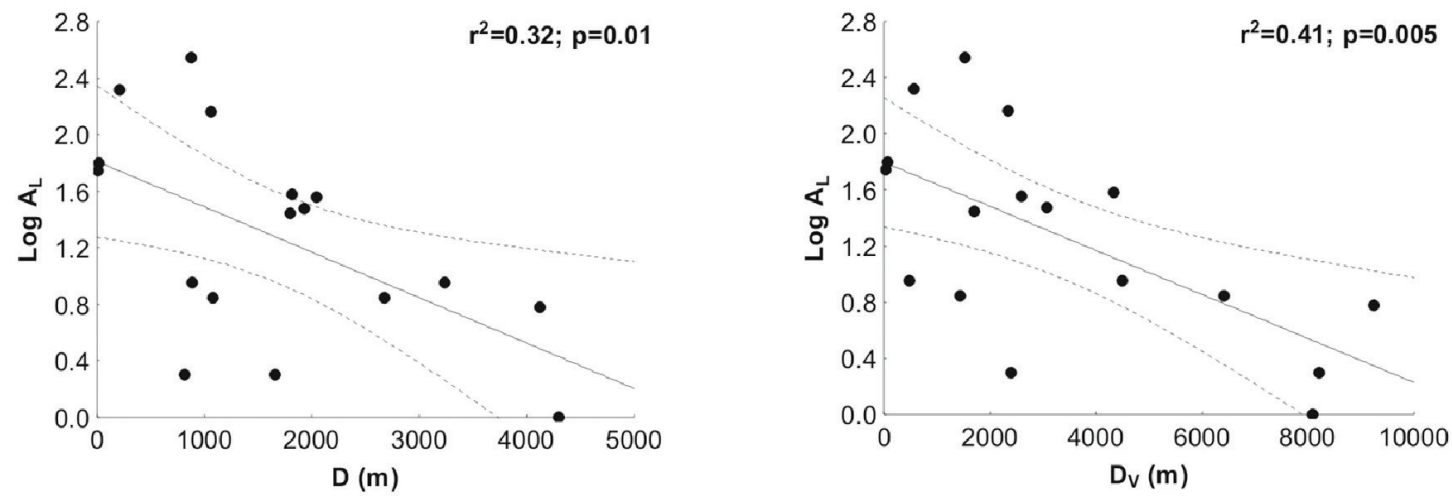

(e)

(f)
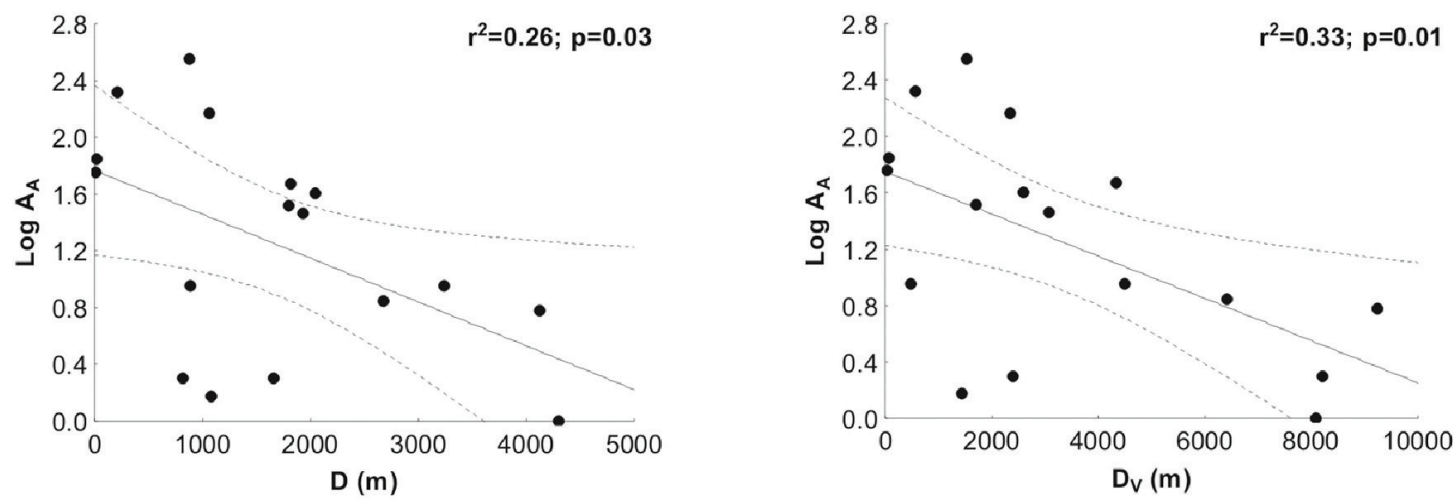

Figure 1. Relationship between distance to nearest forest fragment and abundance of woody, non-planted, native to Atlantic Forest species in restoration sites in the Capivara Reservoir, northern Parana state, Brazil. The three right plots show the relationship between the distance to the nearest forest fragment (in a straight line) (D) and abundance of all species (a), abundance of late successional species (c), abundance of animal-dispersed species (e). The three left plots show the relationship between distance to nearest forest fragment through riparian vegetation $\left(\mathrm{D}_{\mathrm{V}}\right)$ and abundance of all species $(\mathrm{b})$, abundance of late successional species (d), abundance of animal-dispersed species (f).

The landscape surrounding restoration sites proved to be important in both woody species richness and abundance, and thus it matters for the continuity of ecological succession at these sites (Wunderle Jr. 1997; Holl 1999; Holl et al. 2000). Both abundance and species richness were influenced by the distance to seed sources. Further, minimizing travel through the matrix by using riparian vegetation (our $D_{v}$ measure) more than doubled the distance at which the forest fragments exerted their influence, particularly, for animal-dispersed and late successional species (up to $8000 \mathrm{~m}$ ), suggesting a "corridor effect" that can increase connectivity in the fragmented landscape. Although this riparian vegetation is mostly comprised of early reforestation and spontaneous successional stands, forest animals can 
(a)

(b)
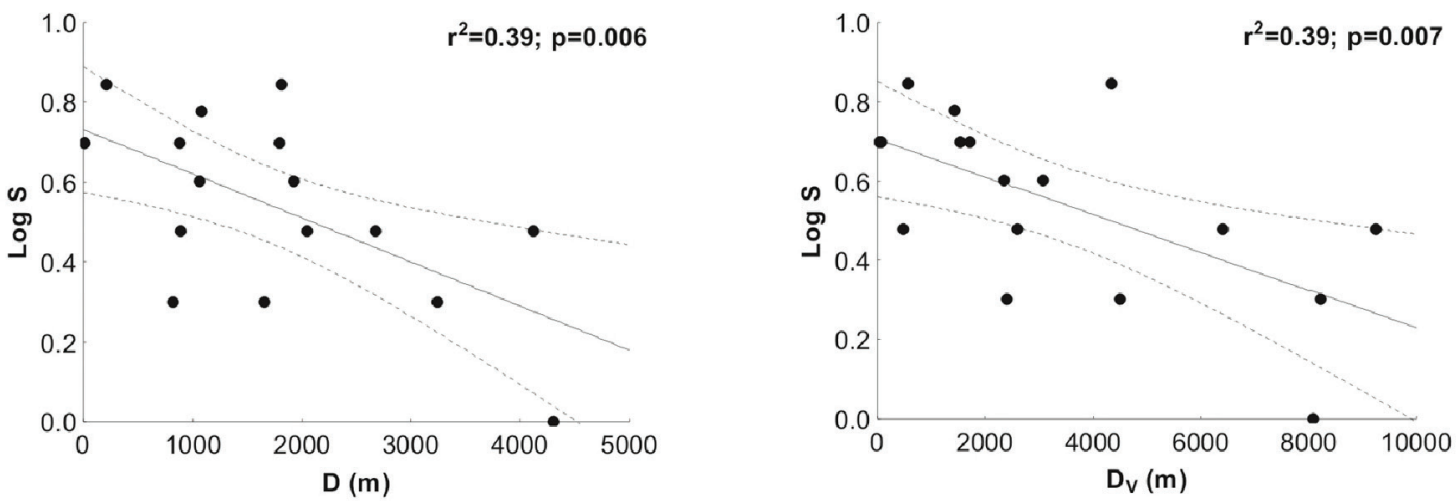

(c)
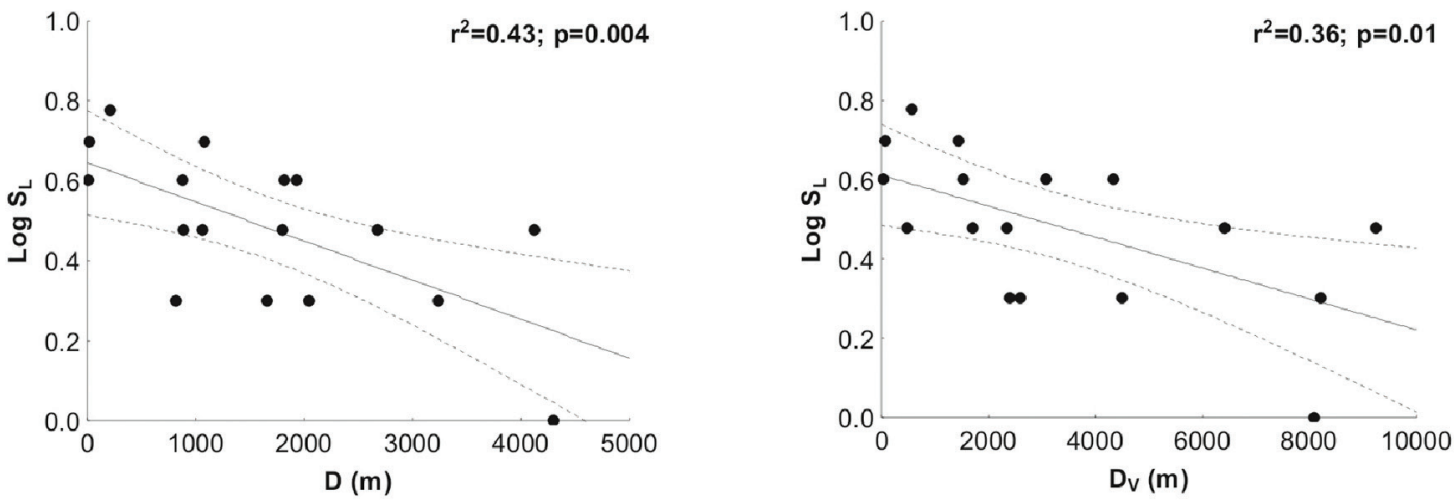

(e)
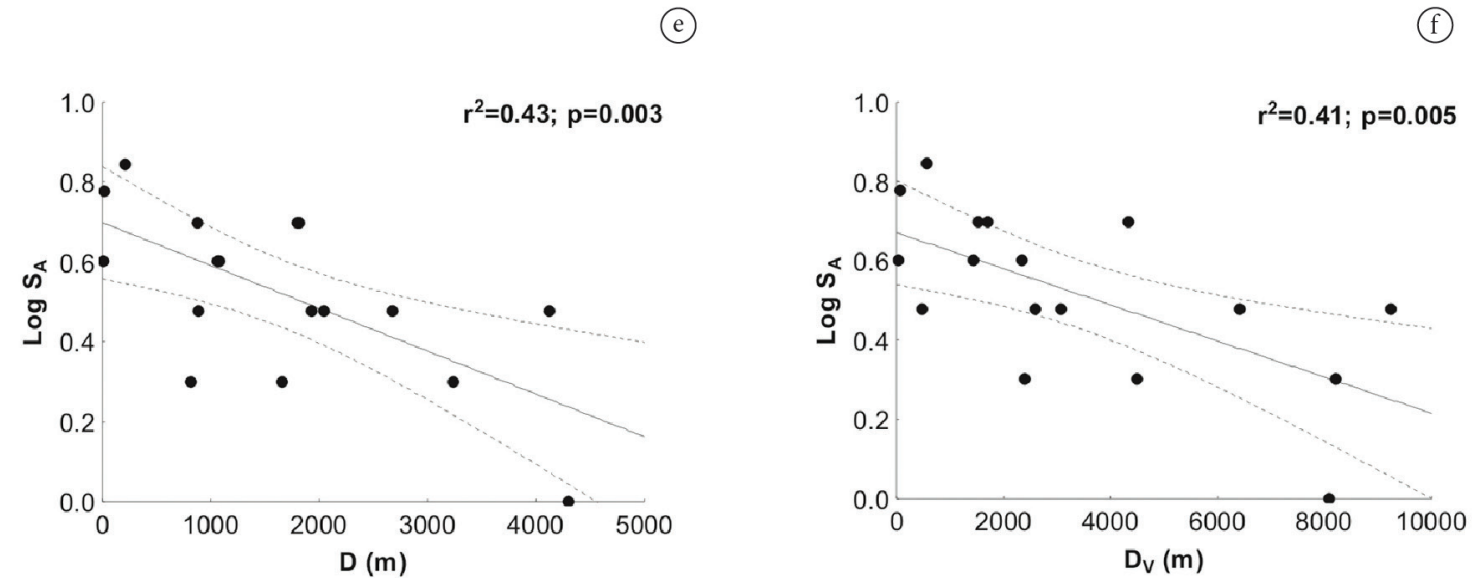

Figure 2. Relationship between distance to nearest forest fragment and species richness of woody, non-planted, native to Atlantic Forest species in restoration sites in the Capivara Reservoir, northern Parana state, Brazil. The three right plots show the relationship between the distance to the nearest forest fragment (in a straight line) (D) and total of species richness (a), richness of late successional species (c), richness of animal-dispersed species (e). The three left plots show the relationship between distance to nearest forest fragment through riparian vegetation $\left(D_{V}\right)$ and total of species richness (b), richness of late successional species (d), richness of animal-dispersed species (f).

use it to avoid inhospitable matrices (Rosenberg et al. 1997; Wunderle Jr. 1997; Beier \& Noss 1998). However, some generalist species may cross limited distances in the matrix (Bierregaard \& Stouffer 1997) and, accordingly, our models suggests that limited seed dispersal may occur for up to $4000 \mathrm{~m}$ in a straight line from the seed source when associated with a larger area of surrounding forests.

One important issue regarding matrix resistance to animal movement is the existence of small-scale structures, such as isolated and grouped trees and small patches of vegetation, 
which can serve as "stepping stones" (Metzger 2000). Our measures of distance to the nearest forest fragment through the matrix do not take into account these structures, generally invisible in mid-resolution satellite imagery.

It is known that the distance from the seed source can be one of the major limiting factors for regeneration in degraded sites (Lamb et al. 1997; Parrotta et al. 1997; Wunderle Jr. 1997; Holl 1999; Holl et al. 2000; White et al. 2004). However, while the distance from the nearest seed source appears to be important for mass seed dispersal, i.e., strongly influencing woody species abundance, forest cover in the immediate vicinity of the restoration sites should be more important in determining species richness. Given that the seeds of a plant species can cross a certain distance threshold, irrespective of whether it is dispersed by animals or wind, it is legitimate to consider that lower distances to cross will imply a higher rate of successful dispersal (White et al. 2004). On the other hand, a greater area of surrounding habitat can mean that more species will survive in the remnant habitat (Tabarelli et al. 1999; Fahrig 2003), and thus more species that are able to disperse through the matrix will succeed in arriving at restoration sites (Parrotta et al. 1997). Our data, however, do not support these suggestions, since surrounding habitat area alone did not explain the abundance and species richness in the reforestation sites. We can speculate that this finding can be related to a limitation of the seed sources itself (poor habitat quality and/or dispersing fauna depletion) or a limitation of the physical environment in the restoration sites (mainly soil and air humidity affecting forest species' ability to establish).

\section{Conclusion}

Closer seed sources promote the arrival of more seeds, and dispersal distances through riparian vegetation strips can be twice those observed in matrix straight-line distances. Thus, restoration planning must take into account the presence of structures such as early successional stands, tiny riparian vegetation remnants, and existing reforestation sites that can serve as corridors.

Against our expectations, a larger area of remnant habitat in the neighborhood does not necessarily means more species are able to disperse to the restoration sites, which points to possible limitations of the potential of forest fragments as seed sources and also to the conditions for establishment in restoration sites. These limitations can be tested through assessments of seed dispersing fauna in the remnants and through seed and seedling transplant experiments; however, sampling the same restoration sites later (e.g., 20 years after planting) will also shed light on the question.

Nonetheless, it is clear that Atlantic Forest remnants of any size and conservation status are crucial for continued succession in restoration sites (and for the ecosystem services expected from them) in the present highly-fragmented landscapes, highlighting the importance of conservation and management of such remnants, even in private lands.

\section{Acknowledgements}

Capes (Brazilian Ministry of Education) provided a graduate grant to LCSMP, and CNPq provided research support and research grants to JMDT. Duke Energy International/ Geração Paranapanema also provided financial support and access permits. Authors are grateful to Dr. Jean Paul Metzger and Dr. Pedro Pedro H. S. Brancalion for the invitation to write for this Special Issue and also Dr. Sandra C. Muller, Dr. Edmilson Bianchini, and two anonymous referees for valuable suggestions and criticism.

\section{References}

Aparicio A et al., 2008. Dispersal potencial determines response of woody plant species richness to environmental factors in fragmented Mediterranean landscapes. Forest Ecology and Management, 255:2894-2906. http://dx.doi.org/10.1016/j. foreco.2008.01.065

Beier P \& Noss RF, 1998. Do habitat corridors provide connectivity? Conservation Biology, 12:1241-1251. http:// dx.doi.org/10.1046/j.1523-1739.1998.98036.x

Bierregaard RO Jr \& Stouffer PC, 1997. Understory birds and dynamics habitat mosaics in Amazonian rainforests. In: Laurance JWF \& Bierregaard RO Jr. Tropical Forest Remnants: Ecology, Management and Conservation of Fragmented Communities. Chicago: University of Chicago Press. p. 138-155.

DeClerck FAJ et al., 2010. Biodiversity conservation in humanmodified landscapes of Mesoamerica: Past, present and future. Biological Conservation, 143:2301-2313. http:// dx.doi.org/10.1016/j.biocon.2010.03.026

Fahrig L, 2003. Effects of habitat fragmentation on biodiversity. Annual Review of Ecology Evolution and Systematics, 34:487-515. http://dx.doi.org/10.1146/annurev. ecolsys.34.011802.132419

García-Feced C, Saura S \& Elena-Roselló R, 2011. Improving landscape connectivity in forest districts: A two-stage process for prioritizing agricultural patches for reforestation. Forest Ecology and Management, 261:154-161. http://dx.doi. org/10.1016/j.foreco.2010.09.047

Hamilton MB, 1999. Tropical tree gene flow and seed dispersal: deforestation affects the genetic structure of the surviving forest fragments. Nature, 401:129-130. http://dx.doi. org/10.1038/43597

Hobbs RJ \& Norton DA, 1996. Towards a conceptual framework for restoration ecology. Restoration Ecology, 4:93-110. http:// dx.doi.org/10.1111/j.1526-100X.1996.tb00112.x

Holl KD, 1999. Factors limiting tropical rain forest regeneration in abandoned pasture: seed rain, seed germination, microclimate, and soil. Biotropica, 31:229-242. http:// dx.doi.org/10.1111/j.1744-7429.1999.tb00135.x

Holl KD et al., 2000. Tropical montane forest restoration in Costa Rica: overcoming barriers to dispersal and 
establishment. Restoration Ecology, 8:339-349. http:// dx.doi.org/10.1046/j.1526-100x.2000.80049.x

Lamb D et al., 1997. Rejoining habitat remnants: restoring degraded rainforest lands. In: Laurance JWF \& Bierregaard RO Jr. Tropical Forest Remnants: Ecology, Management and Conservation of Fragmented Communities. Chicago: University of Chicago Press. p. 366-385.

Laurance WF, 1994. Rainforest fragmentation and the structure of small mammal communities in tropical Queensland. Biological Conservation, 69:23-32. http:// dx.doi.org/10.1016/0006-3207(94)90325-5

Metzger JP \& Décamps H, 1997. The structural connectivity threshold: a hypothesis in conservation biology at the landscape scale. Acta Oecologica, 18:1-12. http://dx.doi. org/10.1016/S1146-609X(97)80075-6

Metzger JP, 2000. Tree functional group richness and landscape structure in a Brazilian tropical fragmented landscape. Ecological Applications, 10:1147-1161. http://dx.doi. org/10.1890/1051-0761(2000)010[1147:TFGRAL]2.0.CO;2

Moles AT \& Westoby M, 2004. Seedling survival and seed size: a synthesis of the literature. Journal of Ecology, 92:372-383. http://dx.doi.org/10.1111/j.0022-0477.2004.00884.x

Parrotta JA, Turnbull JW \& Jones N, 1997. Catalyzing native forest regeneration on degraded tropical lands. Forestry Ecology and Management, 99:1-7. http://dx.doi.org/10.1016/ S0378-1127(97)00190-4

Pivello VR et al., 2006. Chuva de sementes em fragmentos de Floresta Atlântica (São Paulo, SP, Brasil), sob diferentes situações de conectividade, estrutura florestal e proximidade da borda. Acta Botanica Brasilica, 20:845-859. http://dx.doi. org/10.1590/S0102-33062006000400010

Ribeiro MC et al., 2009. The Brazilian Atlantic Forest: How much is left, and how is the remaining forest distributed? Implications for conservation. Biological
Conservation, 142:1141-1153. http://dx.doi.org/10.1016/j. biocon.2009.02.021

Rosenberg DK, Noon BR \& Meslow C, 1997. Biological corridors: form, function, and efficacy. Bioscience, 47:677-687. http:// dx.doi.org/10.2307/1313208

Sansevero JBB et al., 2011. Natural regeneration in plantations of native trees in lowland Brazilian Atlantic forest: community structure, diversity, and dispersal syndromes. Restoration Ecology, 19:379-389. http://dx.doi. org/10.1111/j.1526-100X.2009.00556.X

Tabarelli M, Mantovani W \& Peres CA, 1999. Effects of habitat fragmentation on plant guild structure in the montane Atlantic forest of southeast Brazil. Biological Conservation, 91:119-127. http://dx.doi.org/10.1016/ S0006-3207(99)00085-3

Tabarelli M \& Peres CA, 2002. Abiotic and vertebrate seed dispersal in the Brazilian Atlantic forest: implications for forest regeneration. Biological Conservation, 106:165-176. http://dx.doi.org/10.1016/S0006-3207(01)00243-9

Taylor PD et al., 1993. Connectivity is a vital element of landscape structure. Oikos, 68:571-573. http://dx.doi. org/10.2307/3544927

White E et al., 2004. Seed dispersal to revegetated isolated rainforest patches in North Queensland. Forest Ecology and Management, 192:409-426. http://dx.doi.org/10.1016/j. foreco.2004.02.002

Wunderle JM Jr, 1997. The role of animal seed dispersal in accelerating native forest regeneration on degraded tropical lands. Forest Ecology and Management, 99:223-235. http:// dx.doi.org/10.1016/S0378-1127(97)00208-9

Zanne AE \& Chapman CA, 2001. Expediting reforestation in tropical grasslands: distance and isolation from seed sources in plantations. Ecological Applications, 11:1610-1621. http://dx.doi.org/10.1890/1051-0761(2001)011[1610:ERIT GD]2.0.CO;2 